\title{
Dukungan Sosial Teman Sebaya dan Konsep Diri terhadap Penyesuaian Diri pada Siswa SMA Kelas X
}

\author{
Yusup Adi Saputro ${ }^{1}$, Rini Sugiarti ${ }^{2}$ \\ ${ }^{1.2}$ Magister Psikologi Universitas Semarang \\ Jl. Soekarno Hatta, Tlogosari Kulon, Pedurungan, Kota Semarang, Jawa Tengah 59160 \\ e-mail: putra.yusuf169@gmail.com¹ ${ }^{1}$ rinisugiartipsikologi@usm.ac.id ${ }^{2}$
}

Article History:

Received

22 April 2021

Review

19 Mei 2021

Revised

20 Mei 2021

Accepted

9 Juni 2021

Published

23 Juni 2021

Reviewer A:

Fendy Suhariadi
Abstract. These changes require adolescents to make adjustments to themselves and socially. Thus adolescents are required to build good communication with peers at school and outside of school. The purpose of this study was to determine the effect of peer social support and selfconcept on adjustment in high school students in class $X$. This research method used a quantitative research with a subject of 183 students. The instruments used in this study were self-adjustment scale, peer social support scale, and self-concept scale. data analysis techniques in this study using multiple regression analysis techniques with the help of pls (partial least square). The results of the analysis between peer social support and self-concept towards self-adjustment with a regression coefficient ( $\beta$ ) 0.67 and significant with a P-value of 0.01 means $<0.01$, meaning that it has a positive effect if peer social support and self-concept increases, self-adjustment will also to increase Keywords: peer social support, self-concept, self-adjustment

Abstrak. Perubahan tersebut mengharuskan remaja untuk melakukan penyesuaian dirinya sendiri maupun sosial. Dengan demikian remaja dituntut untuk membangun komunikasi baik dengan teman sebaya di sekolah maupun diluar sekolah. Tujuan penelitian ini adalah untuk mengetahui pengaruh antara dukungan sosial teman sebaya dan konsep diri terhadap penyesuaian diri pada siswa SMA kelas X. metode penelitian ini menggunakan penelitian kuantitaif dengan subjek berjumlah 183 siswa. Instrument yang digunakan dalam penelitian ini adalah skala penyesuaian diri, skala dukungan sosial teman sebaya, dan skala konsep diri. teknik analisis data dalam penelitian ini menggunakan teknik analisis regresi berganda dengan bantuan pls (partial least square). Hasil analisis antara dukungan sosial teman sebaya dan konsep diri terhadap penyesuaian diri dengan nilai koefisien regresi ( $\beta$ ) 0.67 dan signifikan dengan nilai P-value 0.01 artinya $<0.01$, artinya berpengaruh positif jika dukungan sosial teman sebaya dan konsep diri meningkat maka penyesuaian diri juga akan meningkat.

Kata Kunci: dukungan sosial teman sebaya, konsep diri, penyesuaian diri 


\section{Pendahuluan}

Sekolah sebagai salah satu pendidikan formal perlu menyelenggarakan pendidikan yang berkualitas untuk mengembangkan kemampuan siswa. Dalam pengembangan potensi siswa dituntut untuk dapat menyesuaikan diri dengan keadaan dilingkungan mereka sekolah. Menyesuiakan diri bukan berarti siswa berubah menjadi seperti tuntutan dilingkungan sekolah. Hal yang diharapkan siswa dapat memadukan potensi dan kondisi internal dirinya dengan lingkungan tempat berinteraksi. Sekecil apapun perubahan yang terjadi, penyesuaian diri tetap perlu dilakukan agar siswa dapat secara optimal dalam melakukan mengikuti kegiatan di sekolah.

Dalam melewati setiap tahap perkembangan, individu menghadapi masa transisi. Masa transisi dalam tahap perkembangan terjadi ketika anak-anak berkembang menjadi remaja, kemudian berkembang lagi menjadi orang dewasa. Selain transisi dari tahap perkembangan, masa transisi individu juga terjadi di masa sekolahnya. Transisi sekolah adalah perpindahan siswa dari sekolah yang lama ke sekolah baru yang lebih tinggi tingkatannya Mulai dari sekolah dasar menuju sekolah menengah pertama, sekolah menengah atas, hingga menuju perguruan tinggi (Santrock, 2011)..

Perubahan tersebut mengharuskan remaja untuk melakukan penyesuaian dirinya sendiri maupun sosial. Dengan demikian remaja dituntut untuk membangun komunikasi baik dengan teman sebaya di sekolah maupun diluar sekolah (Aristya \& Anizar, 2018). penyesuaian diri itu adalah proses yang meliputi respon mental dan perilaku yang merupakan usaha individu untuk mengatasi dan menguasai kebutuhan-kebutuhan dalam dirinya, ketegangan-ketegangan, frutasi dan konflik-konflik, agar terdapat keselarasan antara tuntutan dari dalam dirinya dengan tuntutan atau harapan dari lingkungan di tempat dia tinggal menurut Schneiders (Agustian, 2009). Menurut hasil penelitian yang telah dilakukan oleh Rokhmatika dan Eko (2013) hubungan antara konsep diri dengan penyesuaian diri disekolah pada siswa unggulan ditemukan adanya hubungan yang positif dan signifikan.

Dukungan sosial teman sebaya adalah dukungan sosial yang bersumber dari teman sebaya dapat memberikan informasi terkait dengan hal apa yang harus dilakukan remaja dalam upaya bersosialisasi dengan lingkungannya, selain itu dapat pula memberikan timbak balik atas apa yang remaja lakukan dalam kelompok dan lingkungan sosialnya serta memberikan kesempatan remaja untuk menguji berbagai macam peran dalam menyelesaikan krisis dalam membentuk identitas diri yang optimal. Menurut penelitian oleh Pratama dan Diana (2017) didapatkan adanya hubungan positif yang 
signifikan antara dukungan sosial teman sebaya dengan motivasi belajar menunjukan bahwa semakin tinggi dukungan sosial teman sebaya, maka semakin tinggi pula motivasi belajar berlaku sebaliknya.

Pemahaman dan penilaian positif terhadap diri sendiri dibutuhkan setiap individu agar individu mampu mengerti dan melakukan apa yang diharapkan oleh lingkungannya, sehingga memudahkannya untuk menyesuaiakan dengan tuntutan lingkungan. Individu dengan konsep diri rendah adalah individu yang mempunyai pandangan negative terhadap dirinya, individu menilai dirinya sebagai figure yang mengecewakan. Hurlock (2016) menyatakan bahwa konsep diri adalah konsep seseorang dari siapa dan apa dia itu. Konsep ini merupakan bayangan cermin, ditentukan sebagian besar oleh peran dan hubungan dengan orang lain, dan apa yang kiranya reaksi orang lain terhadapnya. Menurut penelitian oleh Aristya dan Anizar (2018) artinya ada hubungan positif signifikan antara konsep diri dengan penyesuaian diri remaja di SMA. Hal ini menunjukan ada hubungan dengan arah positif pada konsep diri dan penyesuaian diri.

Berdasarkan pemaparan diatas, kenyataannya terlihat pada siswa SMA dikelas X memiliki permasalahan secara psikologis yang berkaitan dengan penyesuaian diri. Siswa SMA dikelas X juga memerlukan dukungan dari individu-individu terdekat dan konsep diri yang matang dalam proses penyesuaian. Oleh sebab itu peneliti tertarik untuk meneliti pengaruh dukungan sosial teman sebaya dan konsep diri terhadap penyesuaian diri pada siswa sma kelas X.

\section{Kajian teori}

\section{Pengertian Penyesuaian diri}

Penyesuaian diri merupakan salah satu tugas perkembangan masa remaja yang tersulit (Hurlock, 2016). Mengacu pada seberapa jauhnya kepribadian sesorang individu berfungsi secara efisien dalam masyarakat.

Menurut Sobur (2016) penyesuaian diri merupakan faktor yang penting dalam kehidupan manusia. Hidup manusia sejak lahir sampai mati tidak lain adalah penyesuaian diri. Kelainan-kelainan kepribadian tidak lain adalah kelainan-kelainan penyesuaian.

Gerungan (Sunaryo, 2004) penyesuaian diri mengubah diri sesuai dengan keadaan lingkungan, tetapi juga mengubah lingkungan sesuai dengan keadaan keinginan diri.

Menurut Haber \& Runyon (Rufaida \& Erin, 2017) bahwa penyesuaian diri yaitu suatu proses, bukan merupakan keadaan yang statis. Penyesuaian diri dikatakan efektif apabila ditandai dengan seberapa baik individu mampu menghadapi situasi dan kondisi 
yang selalu berganti. Penyesuaian diri menjadi salah satu bekal penting dalam membantu individu pada saat terjun dalam masyarakat luas.

Berdasarkan pemaparan diatas dapat disimpulakan penyesuaian diri adalah kemampuan yang dimiliki individu untuk berinteraksi dengan orang lain yang bertujuan untuk dapat menyelesaikan permasalahan yang dihadapinya, baik secara pribadi ataupun sosial.

\section{Aspek-aspek penyesuaian diri}

Menurut Sundari (2015) karakteristik remaja dalam penyesuaian diri dapat dipaparkan sebagai berikut.

1. Penyesuaian terhadap keluarga (family adjustment), terwujud bila seluruh anggota keluarga mempunyai kesadaran dan kesanggupan memenuhi fungsinya.

2. Penyesuaian diri terhadap sosial (social adjustment), kumpulan individu, keluarga, organisasi, terjadinya keharmonisan dalam masyarakat harus ada kesadaran.

3. Penyesuaian diri terhadap sekolah, sekolah merupakan wadah bagi peserta didik dalam mengembangkan potensinya, terutama perkembangan intelegensi maupun pribadinya.

Penyesuaian diri menurut Scheinders (Aristya \& Anizar, 2018) meliputi empat aspek yaitu:

1. Adaptation adalah penyesuaian diri dipandang sebagai kemampuan seseorang dalam beradaptasi.

2. Comformity adalah seseorang dikatakan mempunyai penyesuaian diri baik bila memenuhi kriteria sosial dan hati nuraninya.

3. Mastery adalah orang yang penyesuaian diri baik mempunyai kemampuan membuat rencana dan mengorganisasikan suatu respon diri.

4. Individual variation adalah ada perbedaan individual pada perilaku dan responnya dalam menanggapi masalah.

Berdasarkan uraian diatas dapat disimpulkan aspek-aspek penyesuaian diri yaitu adaptasi, kesesuaian, penguasaan, dan variasi individu.

\section{Faktor-faktor penyesuaian diri}

Menurut Schneider (Ali \& Mohammad, 2015) setidaknya ada lima faktor yang dapat mempengaruhi proses penyesuaian diri remaja, yaitu:

1. kondisi fisik; berpengaruh kuat terhadap proses penyesuaian diri remaja. 
2. kepribadian; kemauan dan kemampuan untuk berubah, pengaturan diri, realisasi diri, dan intelegensi.

3. edukasi; belajar, pengalaman, latihan, determinasi diri, yang diperoleh dan menyerap ke dalam diri melalui proses belajar.

4. lingkungan; adanya keluarga, lingkungan sekolah, dan lingkungan masyarakat yang berpengaruh terhadap penyesuaian diri.

5. agama dan budaya; faktor agama memiliki sumbangan yang berarti dan budaya juga merupakan faktor yang berpengaruh pada kehidupan individu.

Shcneiders (Agustian, 2009) penyesuaian diri yang dilakukan oleh individu dapat dipengaruhi oleh berbagai faktor, yaitu sebagai berikut:

1. Faktor kondisi fisik, yang meliputi faktor keturunan, kesehatan, bentuk tubuh dan halhal lain yang berkaitan dengan fisik.

2. Faktor perkembangan dan kematangan, yang meliputi perkembangan intelektual, sosial, moral, dan kematangan emosional.

3. Faktor psikologis, yaitu faktor-faktor pengalaman individu, frustasi dan konflik yang dialami, dan kondisi-kondisi psikologis seseorang dalam penyesuaian diri.

4. Faktor lingkungan, yaitu kondisi yang ada pada lingkungan, seperti kondisi keluarga, kondisi rumah.

5. Faktor budaya, termasuk adat istiadat dan agama yang turut mempengaruhi penyesuaian diri seseorang

Berdasarkan uraian diatas dapat disimpulkan faktor-faktor penyesuaian diri yaitu berdasarkan pada diri sendiri, remaja dengan konsep diri tinggi akan lebih memiliki kemampuan untuk melakukan penyesuaian diri yang menyenangkan dibanding remaja dengan konsep diri rendah, pesimis ataupun kurang yakin terhadap dirinya. Berdasarkan dari lingkungan dia tempat tinggal, kelompok teman sebaya ini ada yang menguntungkan pengembangan proses penyesuaian diri tetapi ada pula yang justru menghambat proses penyesuaian diri remaja. Dan faktor berdasarkan perkembangan dan kematangan terutama kematangan emosi yang baik maka remaja mampu menyesuaiakan diri dengan baik sesuai yang diharapkan.

\section{Pengertian dukungan sosial teman sebaya}

Manusia sebagai makhluk sosial tidak dapat hidup sendirian tanpa bantuan orang lain. Kebutuhan fisik (sandang, pangan, papan), kebutuhan sosial (pergaulan, pengakuan, sekolah, pekerjaan) dan kebutuhan psikis termasuk rasa ingin tahu, rasa aman, perasaan religiusitas, tidak mungkin terpenuhin tanpa bantuan orang lain. 
Menurut Sarason (Azizah, 2011) mengatakan bahwa dukungan sosial adalah keberadaan, kesediaan, kepedulian dan orang-orang yang dapat diandalkan, menghargai dan menyayangi kita. Menurut Bandura (Gunarsa \& Yulia, 2017) masa remaja menjadi suatu pertentangan dan pemberontakan karena terlalu menitik beratkan pada ungkapanungkapan bebas dan ringan dari ketidakpatuhan.

Menurut Sarafino (Sasmita \& Rustika, 2015) teman sebaya merupakan sumber dukungan emosional penting sepanjang transisi masa remaja. Dukungan sosial teman sebaya adalah dukungan yang diberikan kepada individu oleh kelompok sebayanya berupa kenyamanan secara fisik dan psikologis sehingga individu merasa dicintai, diperhatikan, dihargai sebagai bagian dari kelompok sosial.

Oktaviana (Mulia, Veny, \& Rismadefi, 2014) mengatakan bahwa dukungan sosial bersumber dari orang-orang yang memiliki hubungan yang berarti bagi individu seperti keluarga, teman dekat, pasangan hidup, rekan kerja, tetangga dan saudara. Teman dekat merupakan sumber dukungan sosial yang utama bagi remaja karena dapat memberikan rasa senang dan dukungan selama mengalami.

Berdasarkan uraian diatas dapat disimpulkan dukungan sosial teman sebaya adalah dukungan yang berasal dari teman dekat yang berupa empati, kasih sayang, perhatian, dan dapat memberikan informasi terkait hal apa yang harus dilakukan remaja dalam upaya bersosialisasi dengan baik pada lingkungannya.

\section{Bentuk-bentuk dukungan sosial teman sebaya}

House (Mahmudi, 2014) membedakan empat bentuk atau dimensi dukungan sosial teman sebaya:

1. Dukungan emosional: mencakup dungkapan empati, kepedulian dan perhatian terhadap orang yang bersangkutan.

2. Dukungan penghargaan: terjadi lewat ungkapan hormat (penghargaan) positif untuk orang itu, dorongan maju atau persetujuan dengan gagasan atau perasaan individu.

3. Dukungan instrumental: mencakup bantuan langsung, seperti kalau orang-orang memberi pinjaman uang kepada orang itu atau menolong dengan pekerjaan pada waktu mengalami stress.

4. Dukungan informatif: mencakup memberi nasehat, petunjuk-petunjuk, saran-sara atau umpan balik.

Sedangkan menurut Sheridan dan Radmacher (Azizah, 2011) membedakan dukungan sosial teman sebaya menjadi lima bentuk, yaitu: 
1. Dukungan instrumental; penyediaan materi yang dapat memberikan pertolongan langsung seperti pinjaman uang, pemberian barang, makanan serta pelayanan.

2. Dukungan informasional; ini melibatkan pemberian informasi, saran atau umpan balik tentang situasi dan kondisi individu.

3. Dukungan emosional; ini membuat individu memiliki perasaan nyaman, yakin, diperdulikan dan dicintai oleh sumber dukungan sosial sehingga individu dapat menghadapi masalah dengan baik.

4. Dukungan pada harga diri; berupa penghargaan positif pada individu, pemberian semangat, persetujuan pada pendapat individu, perbandingan yang positif dengan individu lain.

5. Dukungan dari kelompok sosial; membuat individu merasa anggota dari suatu kelompok yang memiliki kesamaan minat dan aktifitas sosial dengannya.

Dari beberapa pendapat ahli di atas bentuk-bentuk dukungan sosial teman sebaya dapat disimpulkan, adanya dukungan instrumental, dukungan informasi, dukungan emosional, dan dukungan penghargaan.

\section{Pengertian konsep diri}

James menyebutkan bahwa diri yang empiris terdiri atas empat komponen yang diklasifikasikan bagi rasa harga diri, yaitu diri spiritual, diri kebenaran, diri sosial dan diri badaniah (Sobur, 2016). Chaplin (2008) mengemukakan konsep diri adalah evaluasi individu mengenai diri sendiri, penilaian atau penaksiran mengenai diri sendiri oleh individu yang bersangkutan.

Byrne (Sugiarti, 2019), mengemukakan bahwa konsep diri secara khusus dapat diartikan sebagai semua sikap, pikiran dan penerimaan sosial. Konsep diri juga dipandang sebagai kesadaran individu tentang atribut pribadi.

Calhoun dan Acocella (Wienda, 2020), menyatakan konsep diri merupakan gambaran diri sendiri yang meliputi pengetahuan tentang dirinya sendiri, harapan dan penilaian terhadap dirinya. Penghargaan mengenai diri yang positif akan menciptakan bagaimana seseorang bertindak dalam hidup. Menurut tokoh lain mengungkapkan bahwa konsep diri merupakan suatu penilaian mengenai dirinya yang meliputi aspek fisik, aspek psikis, aspek sosial, aspek emosional, aspek aspirasi dan aspek prestasi.

Hurlock (2016) menyatakan bahwa konsep diri adalah konsep seseorang dari siapa dan apa dia itu. Konsep ini merupakan bayangan cermin, ditentukan sebagian besar oleh peran dan hubungan dengan orang lain, dan apayang kiranya reaksi orang lain terhadapnya. 
Menurut Rogers (Sobur, 2016) konsep diri adalah bagian dasar dari ruang fenomenal yang disadari dan disimbolkan, yaitu "aku" merupakan pusat referensi setiap pengalaman. Konsep diri ini merupakan bagian inti dari pengalaman individu secara perlahan-lahan dibedakan dan disimbolkan sebagai bayangan tentang diri yang mengatakan "apa dan siapa aku sebenarnya” dan "apa sebenarnya yang harus aku perbuat". Konsep diri adalah kesadaran batin yang tetap, menganai pengalaman yang berhubungan dengan aku dan membedakan aku dari yang bukan aku.

Dari uraian diatas dapat disimpulkan bahwa konsep diri adalah gambaran diri sebagai kesan terhadap diri sendiri secara keseluruhan dan mendalam yang diberikan secara optimal berdasar pandangan diri sendiri dan pengalaman yang berhubungan dengan orang lain terhadap dirinya.

\section{Aspek-aspek konsep diri}

Menurut Hurlock (2016) menyebutkan ada dua aspek konsep diri yaitu:

1. Aspek fisik, terdiri dari konsep yang dimiliki individu tentang penampilannya, kesesuaian dengan seks, arti penting tubuhnya dalam hubungan dengan perilakunya, dan gengsi yang diberikan tubunya di mata orang lain.

2. Aspek psikologis, terdiri dari konsep inidividu tentang kemampuan dan ketidakmampuannya, harga dirinya dan hubungannya dengan orang lain.

Fitts (Zulkarnain, Sakhyan, \& Raras, 2020) juga mengemukakan terdapatnya aspek lain dari konsep diri yang terdiri atas:

1. Aspek kritik diri yaitu menggambarkan sikap keterbukaan diri dalam menggambarkan diri pribadi.

2. Aspek variabilitas yaitu menggambarkan derajat integritas dan konsistensi persepsi seorang individu tentang dirinya sendiri, dari satu bagian diri kebagian diri lainnya.

3. Aspek distribusi yaitu menggambarkan keyakinan diri atau kemantapan seorang individu dalam menilai dirinya.

Menurut Sari (2020) Ada empat aspek konsep diri menurut pandangan sebagai berikut:

1. Aspek fisik meliputi penilaian individu terhadap segala sesuatu yang dimilikinya.

2. Aspek sosial meliputi bagaimana peranan sosial yang dimainkan oleh individu di lingkungan keluarga, teman, dan kemampuan interaksi sosialnya.

3. Aspek moral meliputi nilai-nilai etika dan moralitas. Setiap pemikiran.

4. Aspek psikis meliputi kognisi, afeksi, dan konasi. 
Berdasarkan uraian diatas dapat disimpulkan bahwa aspek-aspek konsep diri antara lain aspek fisik, aspek moral, aspek sosial, dan aspek psikis.

Siswa kelas X yang baru masuk dilingkungan sekolah dihadapkan dengan tuntutan yang ada di lingkungan sekolah mereka. Kemampuan siswa kelas X mengatur perilakunya terhadap tuntutan tersebut didasarkan pada dukungan sosial teman sebaya dan konsep diri.

Dengan dukungan sosial teman sebaya dan konsep diri yang baik maka dapat menentukan kemampuan penyesuaian diri dalam memenuhi berbagai tuntutan yang ada. Apabila tidak bisa menyesuaiakan diri dengan baik dapat menimbulkan dan kesulitan bagi siswa kelas X di lingkungan sekolah mereka itu sendiri. Hipotesis yang diajukan: ada pengaruh dukungan sosial teman sebaya dan konsep diri terhadap penyesuaian diri pada siswa sma kelas $\mathrm{X}$.

\section{Metode}

Metode yang digunakan dalam penelitian ini adalah penelitian kuantitatif dengan analisis regresi berganda. Terdapat tiga variabel yang akan diketahui yaitu variabel penyesuaian diri, dukungan sosial teman sebaya, dan konsep diri. populasi dalam penelitian ini siswa SMA kela $\mathrm{X}$, berdasarkan jenis kelamin, dan siswa sma kelas X yang masih aktif. Teknik sampling yang digunakan adalah sampling incidental. Teknik pengumpulan data pada penelitian ini menggunakan kuesioner, yaitu menggunakan skala. Skala penyesuaian diri, skala dukungan sosial teman sebaya, dan skala konsep diri yang disusun dengan permodelan skala likert.

Langkah-langkah yang dilakukan membakukan kuesioner penelitian diantaranya:

\section{Uji validitas}

Skala penyesuaian diri memiliki validitas sebesar 0,893 . Skala dukungan sosial teman sebaya memiliki validitas 0.944 . dan skala konsep diri memiliki validitas 0,896.

\section{Uji reliabilitas}

Skala penyesuaian diri memiliki reliabilitas sebesar 0.876. skala dukungan sosial teman sebaya memiliki reliabilitas sebesar 0.939. dan skala konsep diri memiliki reliabilitas sebesar 0.880 .

Table 1. Reliability coefficients

\begin{tabular}{l|l|l}
\hline Y2 & X1 & X2 \\
\hline 0.893 & 0.944 & 0.896 \\
\hline
\end{tabular}


ISSN 2580-6076 (Print), ISSN 2580-8532 (Online)

Teknik analisis data yang digunakan oleh peneliti adalah teknik analisis regresi berganda dengan bantuan teknik korelasi PLS (Partial Least Square).

\section{Hasil dan Pembahasan}

\section{Hasil Penelitian}

\section{a. Korelasi berganda (R)}

$\mathrm{R}$ adalah korelasi berganda, yaitu korelasi antara dua atau lebih variabel independen terhadap dependen. Nilai R berkisar antara 0 sampai 1, jika mendekati 1 maka hubungan semakin erat tetapi jika mendekati 0 maka hubungan semakin lemah. Angka $\mathrm{R}$ diperoleh 0,601, artinya korelasi antara dukungan sosial teman sebaya dan konsep diri terhadap penyesuaian diri sebesar 0.675 , hal ini artinya terjadi adanya pengaruh karena nilainya mendekati 1 . Adjusted $R$ square adalah $\mathrm{R}$ square yang telah disesuaikan, nilai sebesar 0.671, ini juga menunjukan sumbangan pengaruh variable independent terhadap variabel dependent. Standard error of the estimate, adalah ukuran kesalahan prediksi, nilainya sebesar 2.446. Artinya kesalahan dapat terjadi dalam memprediksi penyesuaian diri, yaitu sebesar 2.500 .

\section{Table 2. hasil korelasi PLS}

\begin{tabular}{c|c}
\hline Average R-squared & $0.675, \mathrm{P}<0.001$ \\
\hline Average adjusted R-squared & $0.671, \mathrm{P}<0.001$ \\
\hline Average full collinearity VIF & 2.446 \\
\hline
\end{tabular}

\section{b. Uji hipotesis}

\section{Gambar 1. Uji Hipotesis}

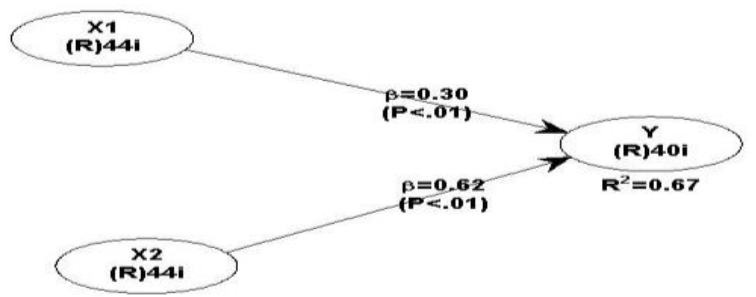

1) Hipotesis pertama diterima artinya dukungan sosial teman sebaya dan konsep diri berpengaruh terhadap penyesuaian diri. dengan memiliki nilai koefisien regresi $(\beta)$ 0.67 dan signifikan dengan nilai P-value 0.01 artinya $<0.01$, artinya berpengaruh positif jika dukungan sosial teman sebaya dan konsep diri meningkat maka penyesuaian diri juga akan meningkat 
2) Hipotesis kedua diterima artinya dukungan sosial teman sebaya berpengaruh terhadap penyesuaian diri dengan memiliki nilai koefisien regresi ( $\beta$ ) 0.30 dan signifikan dengan nilai P-value 0.01 artinya $<0.01$, artinya berpengaruh positif jika dukungan sosial teman sebayameningkat maka penyesuaian diri juga akan meningkat

3) Hipotesis ketiga diterima artinya konsep diri berpengaruh terhadap penyesuaian diri dengan memiliki nilai koefisien regresi $(\beta) 0.62$ dan signifikan dengan nilai P-value 0.01 artinya $<0.01$, artinya berpengaruh positif jika konsep diri meningkat maka penyesuaian diri juga akan meningkat.

\section{Pembahasan}

Berdasarkan hasil dari hipotesis diterima, artinya dukungan sosial teman sebaya dan konsep diri berpengaruh terhadap penyesuaian diri. dengan memiliki nilai koefisien regresi ( $\beta$ ) 0.67 dan signifikan dengan nilai P-value 0.01 artinya $<0.01$, artinya berpengaruh positif jika dukungan sosial teman sebaya dan konsep diri meningkat maka penyesuaian diri juga akan meningkat. Hasil penelitian ini sejalan dengan hasil penelitian yang dilakukan oleh, Rensi dan Sugiarti (2010) bahwa dukungan sosial dan konsep diri pada siswa mempengaruhi prestasi belajar siswa.

Berdasarkan hasil dari hipotesis diterima artinya dukungan sosial teman sebaya berpengaruh positif terhadap penyesuaian diri. dengan memiliki nilai koefisien regresi $(\beta)$ 0.30 dan signifikan dengan nilai P-value 0.01 artinya $<0.01$, artinya berpengaruh positif jika dukungan sosial teman sebaya meningkat maka penyesuaian diri juga akan meningkat. Hasil penelitian ini sejalan dengan hasil penelitian yang dilakukan oleh, Aristya dan Anizar (2018) ada hubungan positif signifikan dukungan sosial dengan penyesuaian diri remaja di SMA.

Berdasarkan hasil dari hipotesis diterima artinya konsep diri berpengaruh terhadap penyesuaian diri. dengan memiliki nilai koefisien regresi $(\beta) 0.62$ dan signifikan dengan nilai P-value 0.01 artinya $<0.01$, artinya berpengaruh positif jika konsep diri meningkat maka penyesuaian diri juga akan meningkat. Menurut peneliti lainnya Semaraputri dan Rustika (2018), bahwa konsep diri memiliki peran yang signifikan terhadap penyesuaian diri pada remaja akhir yang menjadi pengurus organisasi kemahasiswaan di Fakultas Kedokteran Universitas Udayana. Individu dengan konsep diri positif maka penyesuaian diri juga menunjukan positif.

Hal ini mendukung pendapat Gerungan (Sunaryo, 2004) penyesuaian diri mengubah diri sesuai dengan keadaan lingkungan, tetapi juga mengubah lingkungan sesuai dengan keadaan keinginan diri. pendapat Nurs dan Ninuk (2007) hampir setiap 
individu tidak mampu menyelesaikan masalah sendiri, tetapi mereka memerlukan bantuan orang lain. Bahwa dukungan sosial merupakan mediator yang penting dalam menyelesaikan masalah seseorang, hal ini karena individu merupakan bagian dari keluarga, teman sekolah ataupun kerja dan bagian dari kelompok lainnya. Sedangkan menurut Sugiarti (2019) konsep diri merupakan keseluruhan gambaran atribut yang melekat dalam diri individu yang dipengaruhi dari proses kognitif dan lingkungan sosial, dan berpengaruh juga pada afektif dan dalam perilaku, sebagai kekuatan maupun kelemahan dari individu yang bersangkutan.

Berdasarkan uraian diatas terlihat bahwa dukungan sosial teman sebaya dan konsep diri seseorang, yaitu dimana teman sebaya sangat penting untuk memenuhi kebutuhan sosial, kebutuhan akan intimasi meningkat dimasa remaja awal, dan memotivasi remaja mencari sahabat, cara pandang dan penilaian individu pada dirinya sendiri akan berpengaruh terhadap kehidupan sosial seseorang, terutama pada penyesuaian diri.

\section{Simpulan}

Hipotesis pertama ada pengaruh dukungan sosial teman sebaya dan konsep diri terhadap penyesuaian diri, koefisien regresi $(\beta) 0.67$ dan signifikan dengan nilai P-value 0.01 artinya $<0.01$, artinya berpengaruh positif jika dukungan sosial teman sebaya dan konsep diri meningkat maka penyesuaian diri juga akan meningkat.

Hipotesis kedua ada pengaruh dukungan sosial teman terhadap penyesuaian diri, dengan koefisiean regresi $(\beta) 0.30$ dan signifikan dengan nilai P-value 0.01 artinya $<0.01$, artinya berpengaruh positif jika dukungan sosial teman sebayameningkat maka penyesuaian diri juga akan meningkat.

Hipotesis ketiga ada pengaruh konsep diri terhadap penyesuaian diri, dengan koefisiean regresi ( $\beta$ ) 0.62 dan signifikan dengan nilai P-value 0.01 artinya $<0.01$, artinya berpengaruh positif jika konsep diri meningkat maka penyesuaian diri juga akan meningkat.

Maka dapat diambil simpulan bahwa penyesuaian diri dapat dipengaruhi oleh dukungan sosial teman sebaya dan konsep diri yang mempunyai pengaruh secara postitif pada siswa SMA kelas X.

\section{Saran}

Bagi siswa SMA kelas X dapat mempertahankan penyesuaian diri yang baik dan mempertahankan kondisi dukungan dari teman sebaya dan konsep diri dengan baik dan 
cara banyak mengikuti kegiatan-kegiatan ekstrakulikuler di sekolah dan kegiatan di luar lingkungan sekolah.

Bagi peneliti yang lain yang tertarik dan ingin melanjutkan penelitian tentang pengaruh dukungan sosial teman sebaya dan konsep diri terhadap penyesuaian diri pada siswa SMA kelas X dengan memperluas ruang lingkup penelitian dan mengontrol variabelvariabel lainnya.

\section{Kepustakaan}

Agustian, H. (2009). Psikologi Perkembangan "Pendekatan Ekologi Kaitannya dengan Konsep Diri dan Penyesuaian Diri pada Remaja". Jakarta: Refika Aditama.

Ali, M., \& M. A. (2015). Psikologi Remaja. Jakarta: PT.Bumi Aksara.

Aristya, D. N., \& A. R. (2018). Hubungan Dukungan Sosial dan Konsep Diri Dengan Penyesuaian Diri Remaja Kelas X SMA ANGKASA 1 Jakarta. IKRAITH-HUMANIORA, 2.

Azizah, L. M. (2011). Keperawatan Lanjut Usia. Yogyakarta: Graha Ilmu.

Chaplin. (2008). Kamus Lengkap Psikologi. Jakarta: PT. Raja Grafindo Persada.

Gunarsa, S., \& Y. S. (2017). Psikologi Perkembangan Anak \& Remaja. Jakarta: LIBRI.

Hurlock, E. B. (2016). Perkembangan Anak Jilid 2. Jakarta: Erlangga.

Mahmudi, M. H. (2014). Efikasi Diri, Dukungan Sosial dan Penyesuaian diri dalam Belajar. Jurnal Psikologi Indoneia, 3.

Mulia, L. O., V. E., \& R. W. (2014). Hubungan Dukungan Sosial Teman Sebaya Terhadap Tingkat Resiliensi Remaja di Panti Asuhan. JOM PSIK, 1.

Nurs, N. M., \& Ninuk, D. K. (2007). Asuhan Keperawatan Pada Pasien Terinfeksi HIV/AIDS. Jakarta: Salemba Medika.

Pratama, D. W., \& D. R. (2017). Hubungan Dukungan Sosial Teman Sebaya dengan Motivasi Belajar dalam Program Sekolah Lima Hari di SMAN 5 SEMARANG. Jurnal Empati, 6, 231-235.

Rensi, \& Sugiarti, L. R. (2010). Dukungan sosial. konsep diri, dan Prestasi Belajar Siswa SMP Kristen YSKI Semarang. Jurnal psikologi, 3(2), 148-153.

Rokhmatika, L., \& E. D. (2013). Hubungan antara Persepsi terhadap Dukungan Sosial Teman Sebaya dan Konsep Diri dengan Penyesuaian Diri di Sekolah pada Siswa Kelas Unggulan. Journal Mahasiswa Bimbingan dan Konseling, 1.

Rufaida, H., \& E. R. (2017). Hubungan antara Dukungan Sosial Teman Sebaya dengan Penyesuaian Diri pada Mahasiswa Rantau dari Sumatera di Universitas Diponegoro. Jurnal Empati, 7, 217-222. 
ISSN 2580-6076 (Print), ISSN 2580-8532 (Online)

Santrock, J. W. (2011). Life-Span Development "Perkembangan Masa-Hidup Edisi ke13 jilid 1". Jakarta: Penerbit Erlangga.

Sari, U. S. (2020). BODY IMAGE. JAKARTA BARAT: PT. Sahabat Alter Indonesia.

Sasmita, I. A., \& R. I. (2015). Peran Efikasi Diri dan Dukungan Sosial Teman Sebaya terhadap Penyesuaian Diri Mahasiswa Tahun Pertama Program Studi Pendidikan Dokter Fakultas Kedokteran Universitas Udayana. Jurnal Psikologi Udayana, 2.

Semaraputri, S. K., \& Rustika, I. M. (2018). Peran Problem Focused Coping dan Konsep Diri terhadap Penyesuaian Diri pada Remaja Akhir yang Menjadi Pengurus Organisasi Kemahasiswaan di Fakultas Kedokteran Universitas Udayana. Jurnal Psikologi Udayana, 5(1), 35-47.

Sobur, A. (2016). Psikologi Umum. Bandung: Pustaka Setia.

Sugiarti, R. (2019). KARAKTERISTIK SISWA CERDAS ISTIMEWA. Purwokerto: CV. Pena Persada.

Sunaryo. (2004). Psikologi Untuk Keperawatan. Jakarta: Buku Kedokteran EGC.

Sundari, S. H. (2015). Kesehatan Mental dalam Kehidupan. Jakarta: Rineka Cipta.

Wienda, T. A. (2020). Konsep Diri, Regulasi Emosi dan Asertivitas pada Mahasiswa. Philanthropy Journal of Psychology, 4(1), 25-53. 